\title{
Introduction of Tomato Yellow Leaf Curl Virus in Florida and Implications for the Spread of This and Other Geminiviruses of Tomato
}

\author{
J. E. Polston and R. J. McGovern, University of Florida, Gulf Coast Research and Education Center, 5007 60th \\ St. E., Bradenton 34203; and L. G. Brown, Florida Department of Agriculture and Consumer Services, Division of \\ Plant Industry, 1911 S.W. 34th St., Gainesville 32608
}

\begin{abstract}
Polston, J. E., McGovern, R. J., and Brown, L. G. 1999. Introduction of tomato yellow leaf curl virus in Florida and implications for the spread of this and other geminiviruses of tomato. Plant Dis. 83:984-988.

In July 1997, symptoms characteristic of tomato yellow leaf curl virus (TYLCV-Is) were observed on one tomato plant in a field in Collier County, Florida, and on several tomato plants in a retail garden center in Sarasota, Florida. Amplification with three sets of primers, analysis of amplified fragments using restriction enzyme digestion, and hybridization with a clone of TYLCV-Is indicated that TYLCV-Is was present in symptomatic plants. The sequence of a 1,300-bp amplified fragment was 99\% identical to TYLCV-Is from the Dominican Republic and 98\% identical to an isolate from Israel. It appears that TYLCV-Is entered the United States in Dade County, Florida, in late 1996 or early 1997. Subsequently, infected tomato transplants produced for retail sale at two Dade County facilities were rapidly distributed via retail garden centers throughout the state. Infected plants purchased by homeowners and placed in and around homes appeared to be the source of TYLCV-Is for nearby commercial nurseries and production fields. It appears that transplants have played a role in the movement of this and probably other geminiviruses. A number of regulatory procedures, as well as field management practices, were implemented in the 1997-98 production season to minimize the movement of TYLCV-Is within and out of the state.
\end{abstract}

Additional keywords: emerging disease, virus interdiction, virus introduction

Tomato yellow leaf curl virus-Israel (TYLCV-Is) (family Geminiviridae, genus Begomovirus) is a whitefly-transmitted virus first described from infected tomato plants (Lycopersicon esculentum) in Israel almost 40 years ago (5). TYLCV-Is symptoms appear several weeks after infection and include severe stunting, marked reduction in leaf size, upward cupping and chlorosis of leaf margins, mottling, flower abscission, and significant yield reduction. Unlike many other whitefly-transmitted geminiviruses, TYLCV-Is is monopartite and does not require a $\mathrm{B}$ component for infectivity (14). This virus has a broader host range than other whitefly-transmitted geminiviruses and includes vegetable, ornamental, and weed species $(5,6,9)$. TYLCV-Is is readily transmitted in a per-

Corresponding author: J. E. Polston

E-mail: jep@nersp.nerdc.ufl.edu

Florida Agricultural Experiment Station Journal Series R-06728.

Accepted for publication 13 July 1999.

Publication no. D-1999-0920-02S

(C) 1999 The American Phytopathological Society sistent manner by Bemisia tabaci Biotype B (a.k.a. B. argentifolii). In the early 1990s, TYLCV-Is appeared in the eastern Caribbean in Cuba, the Dominican Republic, and Jamaica, and it was believed to have been, in the case of the Dominican Republic, introduced on infected but asymptomatic tomato transplants from the eastern Mediterranean region (4,10-12,17). TYLCVIs can have a catastrophic impact on tomato production and is often associated with high levels of crop losses in both the eastern Mediterranean and the Western Hemisphere $(1,5,15)$. Although no formal crop loss assessment studies have been conducted, an informal survey of growers in the Dominican Republic reported yield losses of up to $95 \%$ in the $1993-94$ production season (1). Management of TYLCV-Is can be difficult, often requiring significant changes in production, management practices, and yield expectations.

It is rare to have the opportunity to document the introduction of a virulent plant virus. The following is an account of the identification of TYLCV-Is in the United States for the first time, its spread within Florida, and the response by university, regulatory, and commercial personnel to contain that spread.

\section{Identification of TYLCV-Is in Florida}

In July 1997, symptoms characteristic of TYLCV-Is were first seen in a tomato plant from a field in Collier County, Florida. At almost the same time, four tomato plants with symptoms typical of TYLCV-Is were found at retail garden centers in West Central Florida (Sarasota and Charlotte counties) (Fig. 1). DNA was extracted from these symptomatic plants for use in polymerase chain reaction (PCR) amplification (17). Primers PAL1v1978 and PAR1c496, degenerate primers that amplify a region that includes a portion of the Rep gene, the intergenic region, and a portion of the coat protein gene of a wide range of both monopartite and bipartite geminiviruses, directed the amplification of a 1,300-bp DNA fragment. Primers PBL1v2040 and PARc154, degenerate primers that amplify an approximately 600-bp region of the B component of many bipartite geminiviruses, did not direct the amplification of a fragment (20). These results suggested that a geminivirus was present in these symptomatic tomato samples and that the size of the amplified A component fragment was similar to that of TYLCV-Is $(12,17)$. Further, like TYLCVIs, this virus appeared not to have a B component. A third set of primers, PTYC1c2140 and PTYC1v2180 (5'-ACTACCATGGCCGCGCAGCGGAATAC-3') was designed to amplify a full-length genome of TYLCV-Is, which is approximately $2,800 \mathrm{bp}$ (13). These primers directed the amplification of a 2,800-bp DNA fragment from the symptomatic tomato samples, as well as from a positive control (an infectious clone of TYLCV-Is previously obtained from a tomato plant in the Dominican Republic).

The 1,300-bp and 2,800-bp DNA fragments amplified from the symptomatic plants from Florida were digested with EcoRI, SacI, ClaI, ApaI, HaeIII, and AluI. Size comparison of these restriction fragments showed a very high degree of homology with those from similar fragments amplified from tomato infected with TYLCV-Is from the Dominican Republic. We observed few polymorphisms. Samples of the five tomato symptomatic plants from 
Florida were blotted onto nylon membranes and probed with $\left[\alpha^{32} \mathrm{P}\right] \mathrm{dCTP}-\mathrm{la}-$ beled DNA of a clone of the intergenic region of TYLCV-Is (pEGF1-12 courtesy of M. K. Nakhla and D. Maxwell) and rinsed under conditions of high stringency (19). Samples from plants with symptoms characteristic of TYLCV-Is hybridized strongly to the probe, whereas samples from tomato mottle virus (ToMoV)-infected plants and asymptomatic plants did not. A PCR-amplified 1,300-bp fragment from one of the symptomatic plants was cloned and sequenced. This sequence was 99\% identical to the infectious TYLCV-Is clone from the Dominican Republic and 98\% identical to TYLCV-Is sequence reported from Israel (accession X15656).

\section{Movement and Distribution of TYLCV-Is in Florida}

In the weeks following initial detection, TYLCV-Is was detected in tomato plants from many locations throughout Florida (Fig. 2A). The virus was detected in tomato plants collected from retail outlets and home gardeners who had purchased plants from retail outlets in Alachua, Charlotte, Sarasota, and St. Lucie counties. Infected plants from all but Alachua County could be traced directly to production facilities in Dade County.

A visit to Dade County in July revealed that symptomatic plants were present in the two retail tomato transplant production sites. At one of these sites, a grower had seen TYLCV-like symptoms in his tomatoes as early as March 1997 but was unaware of the implications. On the same visit, TYLCV-Is-infected plants were detected in one abandoned experimental tomato field in Dade County. Commercial tomato fields had been disked and could not be inspected for TYLCV-infected plants. The commercial growing season for tomato in Dade County is September through April. However, no plants with TYLCV-like symptoms had been reported by growers or IPM scouts during the spring 1997 production season.

It is likely that the virus entered Dade County sometime between fall and spring of the 1996-97 tomato production season. As temperatures increased, whiteflies, and probably the incidence of plants infected with TYLCV-Is, increased in abandoned tomato fields in February and March. It is common in Dade County to abandon tomato fields after harvesting and to disk under crop residue several weeks to months later. TYLCV-Is may have spread from these fields to the tomato plants in nearby greenhouses that were being produced for distribution to garden centers. Tomato plants are shipped year-round from Dade County to retail garden centers, and plants were shipped regularly throughout Florida until July 1997, when TYLCV-Is was detected. Three similar retail tomato production sites in Collier County were

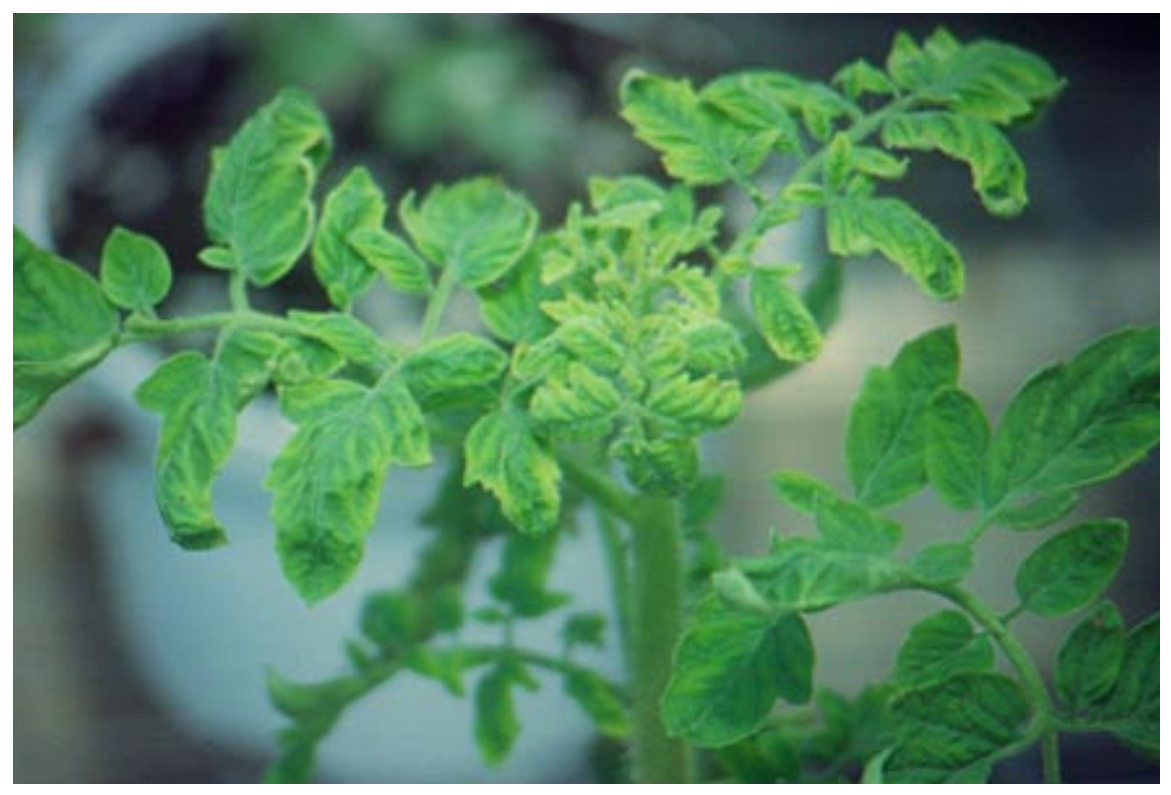

Fig. 1. Lycopersicon esculentum 'Better Bush Improved' infected with tomato yellow leaf curl virus (TYLCV-Is). Plant was purchased at a retail garden center in Sarasota, Florida, in July 1997.

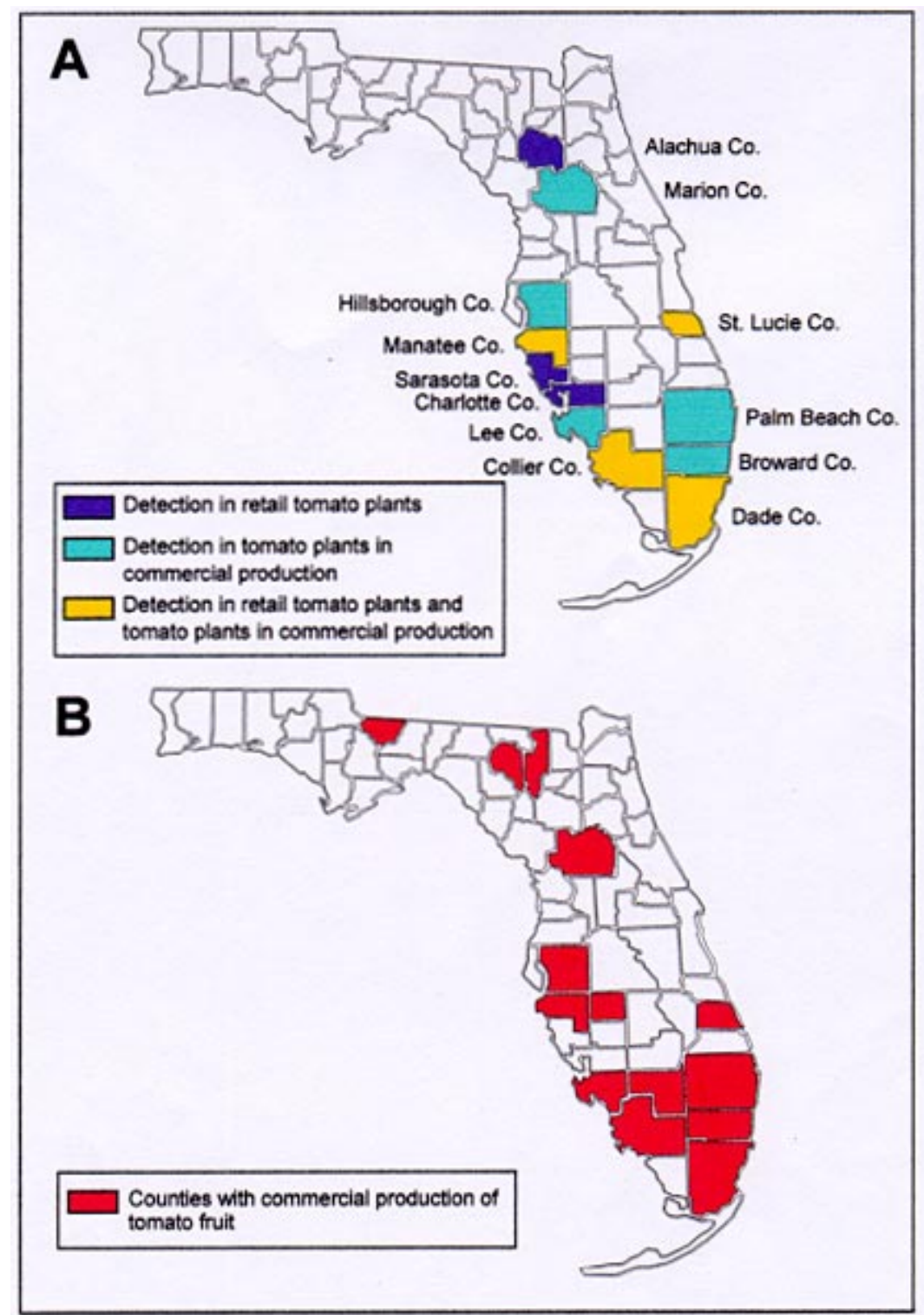

Fig. 2. Maps of Florida showing (A) counties where tomato yellow leaf curl virus (TYLCV-Is) was detected from July 1997 to February 1998, and (B) counties in which tomato fruit are commercially produced. 
examined during the same period. TYLCVIs was not detected, although low incidences of tomato mottle virus (ToMoV) were found.

From at least March until July 1997, tomato plants infected with TYLCV-Is were distributed throughout the state via the retail trade. Based on visual observations and the proximity of residential neighborhoods to some fields and transplant houses, it appears that in some locations, TYLCVIs spread at low rates from infected tomato plants in backyards and patio gardens to nearby tomato fields and greenhouses producing tomato transplants for commercial production. By October 1997, TYLCV-Isinfected plants had been found in commercial tomato fields in Broward, Collier, Dade, Hillsborough, Manatee, St. Lucie, and Palm Beach counties. By February 1998, the virus was also detected in Lee and Marion counties (Fig. 2A) (G. W. Simone, personal communication), and thus had been found in eight out of 10 counties in southern Florida that have commercial tomato production (Fig. 2B).

TYLCV-Is-infected plants appeared in the fall of 1997 in the first half of the growing season at low incidences (less than $0.1 \%$ ) in commercial tomato fields, except in Dade and Palm Beach counties, where TYLCV-Is was found at incidences as high as $15 \%$ in some fields. Little to no spread of TYLCV-Is within most fields was observed. Virus spread was probably restricted because of the application of imidacloprid for whitefly control at transplanting and the roguing of suspiciouslooking plants from fields. Transplants for these fields were not produced in Dade County, but in West Central (Hillsborough, Manatee, Sarasota) and Southwest Florida (Collier, Lee) counties where TYLCV-Is had only been found in retail tomato plants. Some of these plants may have been infected in the transplant production house, but based on the timing of symptom appearance, many of these plants were infected after they had been in the field for several weeks. It is possible that the sources of TYLCV-Is for these few infected field plants were retail plants produced in Dade County that were present in nearby residential areas. It is also possible that some of these plants had become infected in the transplant house. This speculation is supported by the fact that one tomato grower who produces his own transplants for use in fields out-of-state found three TYLCV-Is-infected plants in his out-of-state fields. His production house is located in a residential area, and the source of virus for his transplants was most likely infected retail plants in nearby backyards.

The highest rates of infection in 1997-98 were recorded in Dade and Palm Beach counties. One field in Palm Beach County planted in the fall of 1997 had an estimated final incidence of $10 \%$. The first symptoms of TYLCV-Is appeared in Dade County in September 1997, 4 weeks after transplanting. Incidences of disease in Dade County were generally low from September through January, but they began to increase in February as whitefly populations increased. Incidences of diseased plants were highly variable among fields, ranging from 1 to $100 \%$ by the end of the production season in April 1998.

TYLCV-Is appears to have become established in Dade County. This assumption is based first on the observation that TYLCV-Is-infected plants appeared in September within a few weeks after tomatoes were planted following an almost 3month commercial tomato-free period, and second, by the resurgence of TYLCV-Is in February when whitefly populations began to rise. It is likely that the virus has at least one alternate host species that allows it to survive through the summer when tomato plants are not present in the fields. The establishment of TYLCV-Is in Dade County is a concern for both tomato producers and retail plant producers. The proximity of ornamental and retail vegetable transplant production facilities to commercial tomato fields increases the difficulty of excluding TYLCV-Is from transplants and ornamentals. New regulations for certification of transplants have been imposed in response to the presence of TYLCV-Is. Commercial tomato transplant producers, although not located in Dade County, must comply with these regulations.

\section{Responses to TYLCV-Is in Florida}

Initial responses to the detection of TYLCV-Is were designed to limit the spread of the virus within Florida and to other locations in the United States. Immediately after TYLCV-Is was identified in Florida, an inspection of Dade County nurseries was conducted, and the disease was observed in two production facilities. Infection was confirmed by PCR and blot hybridization. A quarantine on shipments of tomato plants was issued by the Florida Department of Agriculture and Consumer Services, Division of Plant Industry. This quarantine was maintained based on subsequent findings of TYLCV-Is-infected plants but was terminated in mid-September 1997 when it became clear that TYLCV-Is had already spread outside of Dade County. In addition, consumers were reached through county extension personnel, and an appeal was made through local television instructing homeowners how to recognize the symptoms and properly discard infected plants. Commercial tomato transplant producers, tomato growers, extension personnel, state and university officials, and members of the vegetable industry were informed of the presence of TYLCV-Is via meetings held in the four southern Florida tomato production re- gions. These meetings were conducted approximately 1 month after the initial discovery of the virus. Transplant producers were encouraged to apply imidacloprid to all tomato transplants in production at that time. Tomato growers were encouraged to apply imidacloprid at planting to all plants in the fall production season, and to continue to scrupulously manage whiteflies for the entire season. Scouting of fields and roguing of suspicious plants was also recommended. Integrated pest management (IPM) scouts and growers were encouraged to send samples of rogued plants to University of Florida Disease Clinics for confirmation of TYLCV-Is infection.

There was an excellent response by the tomato industry to these recommendations, with many growers following all of them. Infected plants were found by several growers at low incidences in fall production fields in all southern Florida tomato production regions. Grower cooperation was an important component of TYLCV-Is management in this first year. Growers were so successful that very little TYLCVIs was observed in the spring season in most of Florida (with the exception of Dade County).

The United States Department of Agriculture-Animal Plant Health Inspection Service-Plant Protection and Quarantine (USDA-APHIS-PPQ) established a New Pest Advisory Group (NPAG) that met on 28 July 1997. Representatives from USDA-APHIS-PPQ, Florida Department of Agricultural and Consumer ServicesDivision of Plant Industry (FDACS-DPI), the National Plant Board, and the University of Florida, Gulf Coast Research and Education Center, discussed the distribution, likelihood of establishment, and potential for spread of TYLCV.

\section{TYLCV-Is and Transplants}

There is concern by growers, regulatory personnel, and others that TYLCV-Is could move out of Florida to other states and countries. This concern is based on the history of TYLCV-Is in the Dominican Republic and on the rapid movement of TYLCV-Is in Florida in 1997 (15). The probability of movement can be greatly reduced by managing both whiteflies and virus in the tomato fields in the area of the transplant production facilities. In addition, the population of whiteflies and the distribution of TYLCV-Is-infected plants is not likely to be uniform throughout the year, so during certain periods, the probability of spreading the virus through infected transplants will be greater than at other times (18; J. E. Polston, unpublished).

The mechanisms of movement of TYLCV-Is to other states include the movement of virus-infected vegetable as well as ornamental plants, both commercial and retail, and the movement of plants that are not infected with TYLCV-Is but 
are infested with viruliferous whiteflies. There may also be other mechanisms.

The probability of movement, being dependent to some extent upon the rate of infection of transplants and their ability to serve as a source of TYLCV-Is, can be reduced through intervention. The host range of TYLCV-Is in crop, ornamental, and weed species in Florida must be established so that (i) no hosts of TYLCV-Is are distributed without certification, and (ii) steps can be taken to reduce the role of other plants in the infection of transplants. In addition to the factors that affect the likelihood of transplant infection, there are many criteria that determine whether the introduction of a virus will occur and the impact of that introduction (21). Not all introductions of TYLCV-Is will necessarily result in an epidemic or in establishment of the virus.

In October 1997, a meeting of the NPAG and the Southern Plant Board was held in Orlando to review FDACS-DPI's protocol for out-of-state movement of transplants from affected areas. The discussion centered on transplants of three plant species reported as hosts of TYLCV-Is: tomato, tobacco (Nicotiana tabacum), and lisianthus (Eustoma grandiflorum) $(1,3,6)$. From this meeting came a Tomato, Tobacco, and Lisianthus Compliance Agreement (PI275) and a Tomato/Tobacco Plant Certificate (PI-237). Out-of-state shipments of tomato, tobacco, and lisianthus are now regulated by the new PI-237 certificate (based on chapter 581 of the Florida statutes). Since TYLCV-Is does not produce symptoms in lisianthus, tobacco, or young tomato transplants, visual inspection for the presence of TYLCV-Is is not possible. Therefore, in order to be certified, plants must be found to be free of whiteflies ( $B$. tabaci) based on twice-weekly inspections of transplants. It also requires exclusion of whiteflies (either chemically or physically) from the transplant production house.

\section{Conclusions}

It is difficult to determine how TYLCVIs entered Florida because there are several possible means of entry. Dade County is the southernmost county in Florida and includes the city of Miami, a major port of entry for people, plants, and produce. In addition, Dade County is an agriculturally intense production region with ornamental plant nurseries, tropical fruit groves, and vegetable fields, all of which are in close proximity. It is likely that the virus entered the United States either through legally or illegally imported infected plants (fruit tree, vegetable, or ornamental) or through plants infested with viruliferous whiteflies.

The speed and facility with which TYLCV-Is moved throughout Florida was surprising. Also unexpected was the ease with which this virus appeared to move among garden center tomato plants, toma- toes in commercial production, and tomato transplants. Rapid and widespread response by commercial tomato growers in the application of a systemic insecticide, and by IPM scouts and growers in roguing symptomatic plants, aided in maintaining low incidences of this virus in the 1997-98 production season.

The eradication of this virus from Florida is unlikely. Re-introductions of TYLCV-Is can be expected to occur from Dade County to other areas of Florida, since a significant portion of the tomato plants and other ornamental plants for garden centers is produced in Dade County. TYLCV-Is is likely to become established in much of southern Florida due to the endemic populations of whiteflies and the presence of TYLCV hosts.

Transplants appear to have a significant role in the spread of geminiviruses. TYLCV-Is appears to have been introduced into the Dominican Republic in tomato transplants from Israel. The spread of pepper huasteco, Chino del tomate, and Texas pepper geminiviruses within Mexico has been attributed to the movement of infected transplants (22). ToMoV, a geminivirus indigenous to Florida and first observed in 1989, now occurs in other parts of the southeastern United States (1994), Puerto Rico (1995), and Mexico (Yucatan) (1996) in locations that had received tomato transplants from Florida $(3,7,8,16)$. ToMoV resulted in epidemics that lasted for only a limited time in the southeastern United States and in Puerto Rico, whereas the fate of ToMoV in Mexico has not been reported. The introduction of ToMoV into these areas occurred in conjunction with high levels of viruliferous whiteflies in areas where tomato transplants were produced.

In addition to spread by transplants, there are probably other mechanisms by which geminiviruses can be moved over long distances. The appearance of bean golden mosaic virus (BGMV) in Dade County in the fall of 1994 has never been explained (2). Like TYLCV-Is, BGMV reduces yields, and it has become a concern for bean producers. There are other geminiviruses that have appeared recently without explanation, especially in tomato (15).

Current research is focused on identifying crop and weed hosts, monitoring TYLCV-Is in the field and improving management in tomato fields, developing TYLCV-resistant crops, and developing management practices for transplant production houses.

\section{ACKNOWLEDGMENTS}

We thank D. Bois and J. Flaherty for technical assistance, G. W. Simone for records of the Gainesville Plant Disease Clinic, and P. Gilreath, L. Horsman, M. Lamberts, and K. Shuler for information on TYLCV incidences. This work was supported in part by the Florida Tomato Committee.

\section{LITERATURE CITED}

1. Alvarez, P. A., and Abud-Antún, A. J. 1995. Reporte de República Dominicana. CEIBA (Honduras) 36:39-47.

2. Blair, M. W., Bassett, M. J., Abouzid, A. M., Hiebert, E., Polston, J. E., McMillan, R. T., Jr., Graves, W., and Lamberts, M. 1995. Occurrence of bean golden mosaic virus in Florida. Plant Dis. 79:529-533.

3. Brown, J. K., Bird, J., Banks, G., Sosa, M., Kiesler, K., Cabrera, I., and Fornaris, G. 1995. First report of an epidemic in tomato caused by two whitefly-transmitted geminiviruses in Puerto Rico. Plant Dis. 79:1250.

4. Brown, J. K., Lastra, R., and Bird, J. 1992. First documentation of whitefly-transmitted geminiviruses causing widespread disease in cotton, tobacco, and tomato in Dominican Republic and tomato in Puerto Rico. (Abstr.) Phytopathology 82:607.

5. Cohen, S., and Antignus, Y. 1994. Tomato yellow leaf curl virus, a whitefly-borne geminivirus of tomatoes. Pages 259-288 in: Advances in Disease Vector Research. Vol. 10. Springer-Verlag, New York.

6. Cohen, S., Gera, A., Ecker, R., Ben Joseph, R., Perlsman, M., Gokkes, M., Lachman, O., and Antignus, Y. 1995. Lisianthus leaf curl a new disease of lisianthus caused by tomato yellow leaf curl virus. Plant Dis. 79:416-420.

7. Garrido-Ramirez, E. R., and Gilbertson, R. L. 1998. First report of tomato mottle geminivirus infecting tomatoes in Yucatan, Mexico. Plant Dis. 82:592.

8. Hiebert, E., Abouzid, A. M., and Polston, J. E. 1995. Whitefly-transmitted geminiviruses. Pages 277-288 in: Bemisia: Taxonomy, Biology, Damage, Control and Management. D. Gerling and R. T. Mayer, eds. Intercept Press, Andover, UK.

9. Mansour, A., and Al-Musa, A. 1992. Tomato yellow leaf curl virus: Host range and virusvector relationships. Plant Pathol. 41:122125.

10. Martinez-Zubiaur, Y., Zabalgogeazcoa, I., De Blas, C., Sanchez, F., Peralta, L., Romero, J., and Ponz, F. 1996. Geminiviruses associated with diseased tomatoes in Cuba. J. Phytopathol. 144:277-279.

11. McGlashan, D., Polston, J. E., and Bois, D. 1994. Tomato yellow leaf curl geminivirus in Jamaica. Plant Dis. 78:1219.

12. Nakhla, M. K., Maxwell, D. P., Martinez, R. T., Carvalho, M. G., and Gilbertson, R. L. Widespread occurrence of the Eastern Mediterranean strain of tomato yellow leaf curl geminivirus in tomatoes in the Dominican Republic. Plant Dis. 78:926.

13. Nakhla, M. K., Mazyad, H. M., and Maxwell, D. P. 1993. Molecular characterization of four tomato yellow leaf curl virus isolates from Egypt and development of diagnostic methods. Phytopathol. Mediterr. 32:163-173.

14. Navot, N., Pichersky, E., Zeidan, M., Zamir, D., and Czosnek, H. 1991. Tomato yellow leaf curl virus: A whitefly-transmitted geminivirus with a single genomic component. Virology 185:151-161.

15. Polston, J. E., and Anderson, P. K. 1997. The emergence of whitefly-transmitted geminiviruses in tomato in the Western Hemisphere. Plant Dis. 81:1358-1369.

16. Polston, J. E., Bois, D., Keinath, A. P., and Chellemi, D. O. 1995. Occurrence of tomato mottle geminivirus in South Carolina, Tennessee, and Virginia. Plant Dis. 79:539.

17. Polston, J. E., Bois, D., Serra, C.-A., and Concepcion, S. 1994. First report of a tomato yellow leaf curl-like geminivirus in the Western Hemisphere. Plant Dis. 78:831.

18. Polston, J. E., Chellemi, D. O., Schuster, D. J., McGovern, R. J., and Stansly, P. A. 1996. Spatial and temporal dynamics of tomato 
mottle geminivirus and Bemisia tabaci in Florida tomato fields. Plant Dis. 80:10221028.

19. Polston, J. E., Hiebert, E., McGovern, R. J., Stansly, P. A., and Schuster, D. J. 1993. Host range of tomato mottle virus, a new geminivirus infecting tomato in Florida. Plant Dis. 77:1181-1184.

20. Rojas, M. R., Gilbertson, R. L., Russell, D.
R., and Maxwell, D. P. 1993. Use of degenerate primers in the polymerase chain reaction to detect whitefly-transmitted geminiviruses. Plant Dis. 77:340-347.

21. Royer, M. H., and Dowler, W. M. 1985. Assessing the threat of foreign plant pathogens after entry. Pages 583-594 in: The Movement and Dispersal of Agriculturally Important Biotic Agents. D. R. MacKenzie, C. S. Barfield,
G. G. Kennedy, R. D. Berger, and D. J. Taranto, eds. Claitor's Publishing Division, Baton Rouge, LA.

22. Torres-Pacheco, I., Garzón-Tiznado, J. A., Brown, J. K., Becerra-Flora, A., and RiveraBustamante, R. F. 1996. Detection and distribution of geminiviruses in Mexico and the southern United States. Phytopathology 86:1186-1192. 